\title{
Green Revolution and Redistribution of Rural Incomes: Pakistan's Experience
}

\author{
M. GHAFFAR CHAUDHRY*
}

The paper investigates the legitimacy of the popular view that the Green Revolution has led to a magnification of income inequality in rural Pakistan. The empirical evidence produced in this paper is sufficiently conclusive to show that the Green Revolution has actually been responsible for reduction of income disparity between small and large farms, between farm and non-farm rural classes and between well-to-do and poorer agricultural regions in Pakistan. The paper suggests that Green Revolution technologies should be encouraged in the interest of economic development.

\section{INTRODUCTION}

There is little doubt that Green Revolution has contributed significantly to increasing agricultural production in Pakistan. It directly contributed to the development of surface- and ground-water aquifers, rising input of fertilizer, the adoption of High-Yielding Varieties (HYVs) and the introduction of tractors. But skepticism prevails as to its efficacy as a redistributive device. In fact it has been argued that Green Revolution actually widened rural income inequalities $[5 ; 15 ; 20$; $21 ; 22 ; 23 ; 25 ; 26 ; 33 ; 36 ; 42 ; 45$ and 73 ]. This view-point is based on a number of theoretical arguments postulating varying impacts of Green Revolution on the incomes of large farmers and small farmers ${ }^{1}$, land-owners and the rural landless, and different agricultural regions variously endowed with resources and potentials. With respect to the growing income disparities between farmers, it is argued that the technology that goes with Green Revolution is basically indivisible [15, p.706 and 21, p.364]. Since tubewells and tractors require lump-sum investments, they are

* The author is a Senior Research Economist at the Pakistan Institute of Development Economics (PIDE), Islamabad. The paper draws heavily on his Ph.D dissertation written at the University of Wisconsin, Madison (U.S.A.) with financial support from Ford Foundation and the PIDE. He owes a great debt of gratitude to his academic adviser, Professor Don $\mathrm{K}$ anel and his thesis committee member, Professor William C. Thiesenhusen for offering constructive criticisms and editorial comments on the various drafts of the dissertation. The author is also most grateful to Professor Syed Nawab Haider Naqvi for his invaluable advice and encouragement. Editorial help from Syed Hamid Hasan Naqavi is much appreciated. However, the author alone is responsible for the errors, omissions and ideas of this manuscript.

${ }^{1}$ It is conventional to define a small farmer as one who works a farm of a less than 12.5 acres. This definition is retained throughout this paper unless otherwise specified. By contrast, a large farmer operates more than 50 acres. 
beyond the purchasing power of the small farmers. The use of chemical fertilizers and the adoption of HYVs depend critically on irrigation-water availability and follow the pattern of tubewell concentration [15, p.699]. Because of the heavy use of fertilizer and a greater marketed surplus on large farms, the major benefits of input subsidy and price support programmes remain confined to large farmers alone $[15$, p.707]. The greater access of the large farmers to cheap institutional credit and to extension and research services has gone a long way to accentuate the above situation [21, p.371 and 73, p.196]. It is also claimed that a higher percentage of high-value cash crops is grown on large farms than on small farms [21, p.364]. All these developments, it is believed, have substantially raised productivity on large farms in contrast to only negligible productivity gains on small farms [73, p.193] The productivity-induced income increases have enabled the large farmers to engage in land purchases and/or land-renting resulting in a more skewed pattern of land distribution [5, p.333; 15, p.706; 20, pp.53-54 and 73,p.198]

It has also been argued that while the Green Revolution has benefited land owners in varying degrees, it has been responsible for a progressive reduction of the income-earning prospects of the rural landless. For example, while the rising profitability of agriculture under the Green Revolution has promoted owner-cultivation on large farms, it has led to tenant evictions from those farms. The introduction of tractors and installation of tubewells have reduced the share of tenants in total agricultural produce $[5, \mathrm{p} .337]$. Furthermore, tractorization may have been responsible for a large-scale displacement of labour $[15$, p.705; 23, p.53 and 42, p.586]. The substitution of wheat (a less labour-intensive crop) for cotton (a more labourintensive crop) induced by greater profits from cultivation of HYVs of the former crop than from cotton cultivation may also have contributed to greater unemployment in the rural areas $[15$, p. $705 ; 23$, p.53 and 45, p.113]

The question of rising regional income differentials hinges primarily on timely availability of adequate irrigation water. It has been argued [15, p.701] that new varieties of wheat and rice require controlled irrigation. In the absence of such controls, any amount of fertilizer application would lead to only modest increments in output. Furthermore, without new seeds and fertilizer, the possibilities of securing rapid increases in agricultural output are quite limited. For this reason, irrigated areas may have taken a lead in productivity over the unirrigated ones. Arguing along these lines, Alavi [5, p.328] and Griffin [23, p.207] contend that Green Revolution occurred chiefly in the prosperous areas of the Punjab because of tubewell concentration there rather than in Baluchistan, N.-W.F.P. or Sind.

Green Revolution would indeed have exacerbated rural income inequalities if all that has been said so far accorded with the actual conditions prevailing in Pakis$\tan$. It will be shown in this paper that the majority of the above arguments are not correct, and that part of the evidence which has been used to demonstrate the adverse consequences of Green Revolution on income distribution is particularly untrustworthy. The paper also demonstrates that Green Revolution has been the most viable rural development strategy ever pursued in Pakistan.

The paper is spread over five sections. The analysis in the second Section pertains to the changes in the incomes of small and large farmers. The effects of the Green Revolution technologies on employment and incomes of the rural landless are discussed in Section 3. Section 4 answers some of the questions related to changes in regional distribution of income induced by Green Revolution. While Sections 2-4 deal with changes in functional distribution of rural incomes, the emphasis in Section 5 is on aggregate size distribution of rural incomes. The last Section, briefly discusses the main findings of this paper along with their policy implications for agricultural growth in Pakistan.

\section{INTER-FARM INCOME DISPARITIES}

An idea of the trend of income distribution in an economy composed of small and large farmers in the agricultural sector can be approximated by comparing the growth rates of incomes of these two groups of farmers. In line with the technique used in the existing literature, changes in farm income have been disaggregated into changes in farm productivity (product per acre) and changes in farm size (i.e. land distribution). The objective in this section is to study the implication of both these measures for income distribution in the agricultural sector.

\section{Trend of Farm Productivity}

With farm size remaining constant, changes in farm productivity will be equal to changes in farm income. It may be interesting to note that changes in farm productivity are a function, not only of the level of use but also of the proportion in which various traditional, modern and managerial inputs are combined in the production process [30, p.571]. This is to say that larger doses of modern inputs alone are not sufficient to raise land productivity. Such inputs must be supplemented by 'adequate' amounts of traditional and managerial inputs. Thus the level and trend of Farm productivities must be studied in the light of the totality of input use rather than the use of modern inputs only, especially in view of the possibilities of substitution between traditional, modern and managerial inputs. The analysis of input use in the following paragraphs is specifically designed for analysing productivity changes on small and large farms.

One is likely to get a mixed picture of fertilizer use on small and large farms depending on the type of the crop grown and the risk involved in adopting the new technology. According to a 1969-70 study by the Government of the Punjab, small farmers holding less than 12.5 acres of land applied 41 nutrient pounds of chemical fertilizer to Mexican Wheat as against 62 pounds used by large farmers operating more than 25 acres [74]. Similarly, Azam's survey for 1970-71 [6, pp.424-429] 
concluded that fertilizer use for wheat in the case of small farmers varied between 51 and 61 nutrient pounds compared with 75 pounds by those having more than 25 acres. By contrast, Azam's data also show that the level of fertilizer application in case of non-food crops and the rate of growth of fertilizer application for all crops was higher on small farms than on large farms [6, pp.424-429]. In view of the rapidly rising use of fertilizer on small farms, it is not surprising that Salam's study [82, p.320], based on 1972-73 data, and General Farmer's Investigation Survey for 1975-76 and follow-up study for 1977-78, both noted in [70, pp.67-70 and 71, p.76] report higher doses of fertilizer application by small farmers than those by large farmers. Because of a rapid increase in fertilizer prices during 1979-80 and 1980-81, small farm seem to have lagged behind large farm in fertilizer use. The studies done by National Fertilizer Corporation of Pakistan [70 and 71] show no material differences in fertilizer input for maize and sugarcane on large and small farms. However, in the case of wheat, cotton and rice, fertilizer input is 7 nutrient pound higher on large farms than on small farms.

While the differences in fertilizer input on large and small farmers are negligible at present, they have been more than offset by the higher manurial input on small farms. For example, it has been reported that on an average small farmers use twice as much farm-yard manure per acre as do large farmers [12, p.248]. With a normal four-ton dose the use of farm-yard manure on small farms exceeds by two tons the amounts used by large farms. Since farm-yard manure contains 0.6 percent nitrogen, 0.15 percent phosphorous and 0.45 percent potassium [28, pp.19-21], a two-ton higher application rate on small farms will be equivalent to 24 nutrient pounds of nitrogen in addition to 6 pounds of phosphorous and 18 pounds of potassium. Thus although the small farmers may have been using lesser fertilizer than large farmers, the higher manurial input has enabled the small farmers to secure a higher and better soil-nutrient balance than is obtained by large farmers.

Similarly, the large farmers seem to have played a leadership role in the adoption of HYVs. Most of the studies conducted during the late Sixties and early Seventies $[6$, pp.404-429;39, p.4 and 74] have reported 7-10 percent higher adoption rates for HYVs by large farmers than those by small ones. Johnston and Kilby, however, have argued that there has been a gradual narrowing of these differentials because of a rapid growth of the area using HYVs on small farms [31, pp.401402]. The 1972 Agricultural Census data show that these differentials had disappeared by $1971-72$, as both small and large farmers devoted 52 percent of their total wheat area to high-yielding varieties of wheat $[62, p .16]$. The difference between large and small farmers in the adoption of HYVs of rice is more pronounced. According to the 1972 Agricultural Census, small farmers devoted only 11.7 percent of their rice area to IRRI rice as compared to large farmers' 47.1 percent $[62, \mathrm{p} .18]$. This fact, however, may not have been a decisive evidence to prove the higher productivity of large farmers. This is because the small farmers tend to allocate a greater proportion (47.1 percent) of their rice area to high-value Basmati rice than do large farmers (21.0 percent). IRRI rice yields are no doubt 70 percent high than those of Basmati rice but Basmati rice commands twice as much price as the rice. Thus, with a greater proportion of rice area devoted to Basmati, small farmers enjoy greater returns on their investment then do the large farmers.

Unlike fertilizers and HYVs, tubewells and tractors require lump-sum investments. They are, therefore, concentrated mainly on large farms, as is evident from the 1972 Agricultural Census data. Small farms, which represent 66 percent of the total number of farms in Pakistan, own only 27 percent of the country's tubewells and 9 percent of the tractors. By contrast, large farms, account for more than 24 percent of the tubewells and 53 percent of the tractors [62, pp.20-21].

Productivity per acre would indeed be higher on large farms than small ones if the concentration of tubewells and tractors leads to a higher proportion of irrigated area, more intensive land utilization and a shift to cash crops. This, however, has not been the case in Pakistan partly because the small farms by their very nature are easy to manage and have continued to depend heavily on traditional means of irrigation water (Persian wheel) and draught power in view of the excess human and animal labour; and also because tubewell and tractor services can be easily purchased in the open market. Johnston and Kilby have noted that the practice of selling tubewell water to nearby farmers and the institution of contract ploughing make tubewells and tractors quite divisible [31, p.149] in terms of the flow of their services. As a result, small farmers have been able to maintain a competitive edge over the large farmers. For example, in 1971-72 more than 79 percent of the cropped area owned by small farmers benefited from irrigation facilities as against 60 percent owned by large farmers [62, p.11]. More surprising is the fact that between 1960 and 1972 the annual growth of irrigated area ( 0.80 percent) has been faster in the case of small farms than that on large farms ( 0.75 percent) [52, p.73 and 62, p.11]. Similarly, the cropping intensity on small farms (122.6 percent) exceeded that on large farms (94.6 percent) [62, p.9]. This holds also for the land-use intensity (the percentage of the farm area cultivated): 93 percent of farm land is currently under plough on small farms as compared to 61.5 percent on large farms $[62, p .8]$. The percentage area under cash crops including cotton, sugarcane, rice, fruits and vegetables was 29 on small farms and 28 on large farms in 1971-72 [62, p.15].

It should be apparent from the above analysis that, in spite of their financial stringencies, small farmers have been at least as much enterprising as large farmers in adopting new inputs. This observation contradicts the widely-held opinion that because of their financial superiority and their easier access to governments credit, research and extension programmes, large farmer use inputs more intensively than the small farmers. While small farmers re-invest most of their income on their farms, large farmers generally tend to spend the bulk of their income on luxuries so that where agricultural operations are concerned, large farmers do not have the financial 
advantage over small farmers that they are generally held to have. Furthermore, the greater access of large farmers to institutional credit would by itself be not enough to cause any notable difference in input use because institutional credit represents only a small fraction of the total available credit in the agriculture sector: more than 90 percent of the credit requirements in agriculture are met by private, interest-free credit [72, pp.56-57].

We now turn to a discussion of the relative magnitudes and trends of productivity of small as well as large farms. In view of the higher use of inputs (both modern and traditional) and better managerial ability of the small family-farms, it seems natural to expect that small farms would be more productive than large farms. Similarly, the productivity of the small farms may be expected to grow at a faster rate than that of large farms because of the more rapid increase in critical inputs of chemical fertilizer and irrigation water on small farms. These assertions, however, remain to be verified by direct empirical evidence in Pakistan. The only data that allow productivity comparisons by farm size in Pakistan are those given in the 'Farm Accounts and Family Budgets (FAFB) of cultivators in the Punjab' issued by the Punjab Board of Economic Inquiry $(75-79)^{2}$ The FAFB data, weighted by the proportionate irrigated area [13, p.84], are reproduced in Table 1.

The data presented in Table 1 lend support to the a priori belief that small farms are more productive than large farms. This conclusion remains valid whether the productivity is defined in terms of gross income or net income per farm acre. Over the period from 1965-66 to 1970-71, the gross productivity of small farms went up from Rs. 363 to Rs. 715. By contrast, that of large farms rose from Rs. 205 to Rs. 332 only. The increase in the net productivity of small farms ranged from Rs. 262 in 1965-66 to Rs. 581 in 1970-71 against the corresponding increase on farms from Rs. 132 to Rs. 207. Thus, between 1965-66 and 1970-71, the per acre incomes of the small farms almost doubled while those of large farms increased by only $55-60$ percent.

\section{Distribution of Agricultural Land}

On the basis of the trends of relative productivity of small and large farms under Green Revolution, it may not be unjustified to conclude that Green Revolution in Pakistan has had a positive impact on income distribution. However, to establish the result firmly it is also necessary to show that changes in land distribution induced by Green Revolution have not been adverse to the small farmers. Since the rate of change in farm incomes is a sum total of the rates of change in

${ }^{2}$ In spite of the smallness of the sample, we may place a reasonable degree of confidence in the reliability of the FAFB data because the sample is carefully drawn to represent the actual conditions in Pakistan [27, p.262]. These data are reliable also because the trained personnel of the Punjab Board of Economic Enquiry normally keep the identity of the respondents year after year [13, pp.70-71] farm productivity and farm size, the land distribution changes are a crucial factor in the determination of income distribution among the farming community. The importance of this factor cannot be underestimated, for a serious increase in land concentration in response to land purchases or land renting by large farmers could reverse the trend of productivity-based income distribution.

\section{Table 1}

Gross and Net Incomes* per Farm Acre on Small and Large Farms 1965-66 to 1970-71

\begin{tabular}{llllll}
\hline \multirow{2}{*}{$\begin{array}{l}\text { Farm Size and } \\
\text { Years }\end{array}$} & \multicolumn{2}{c}{ Income (Rs.) Per Acre } & & \multicolumn{2}{c}{ Productivity Index } \\
\cline { 5 - 6 } & Gross & Net & & Gross & Net \\
\hline A. Small Farms & & & & \\
$1965-66$ & 363.3 & 262.4 & & 100.0 & 100.0 \\
$1966-67$ & 515.5 & 403.4 & & 141.9 & 153.7 \\
$1967-68$ & 579.1 & 468.4 & 159.4 & 178.5 \\
$1968-69$ & 534.6 & 443.3 & 150.2 & 168.9 \\
$1969-70$ & 657.6 & 516.0 & 181.0 & 196.6 \\
$1970-71$ & 714.6 & 581.4 & 196.7 & 221.6 \\
& & & & \\
B. Large Farms & & & & \\
$1965-66$ & 205.2 & 132.3 & 100.0 & 100.0 \\
$1966-67$ & 250.1 & 178.0 & 121.9 & 134.5 \\
$1967-68$ & 230.3 & 157.2 & 112.2 & 118.8 \\
$1968-69$ & 250.0 & 171.2 & 121.8 & 129.4 \\
$1969-70$ & 342.5 & 243.2 & 166.9 & 183.8 \\
$1970-71$ & 332.3 & 206.9 & 161.9 & 156.4 \\
\hline
\end{tabular}

Source: Calculations based on data in $[52 ; 62 ; 75 ; 76 ; 77 ; 78$ and 79$]$. areas.

${ }^{*}$ Gross and net incomes per acre are weighted averages of the irrigated and unirrigated

Fortunately, the agricultural censuses of 1960 [52] and 1972 [62] provide comparative data on operational holdings. These data can be used for the purpose in hand. Based on the information included in the two censuses, Table 2 gives the land shares of various percentiles of farms along with land-concentration ratios.

The land shares and land concentration ratios reported in Table 2 show a trend towards a more egalitarian land distribution pattern between 1960 and 1972. In terms of land shares, the smallest 10 percent of the farms operated 0.88 percent of the total farm area in 1972 in contrast to 0.46 percent in 1960 . By comparison, the 
Table 2

Percentile Land Shares and Land Concentration Ratios for 1960 and 1972

\begin{tabular}{|c|c|c|c|}
\hline \multirow{2}{*}{ Percentage of Farms } & & \multicolumn{2}{|c|}{ Cumulative Land Shares for } \\
\hline & & 1960 & 1972 \\
\hline \multicolumn{2}{|l|}{ Lowest 10 percent } & 0.46 & 0.88 \\
\hline \multicolumn{2}{|l|}{ Lowest 20 percent } & 1.44 & 3.02 \\
\hline \multicolumn{2}{|l|}{ Lowest 30 percent } & 3.00 & 6.07 \\
\hline \multicolumn{2}{|l|}{ Lowest 40 percent } & 6.00 & 10.60 \\
\hline \multicolumn{2}{|l|}{ Lowest 50 percent } & 9.72 & 16.09 \\
\hline \multicolumn{2}{|l|}{ Lowest 60 percent } & 15.79 & 24.41 \\
\hline \multicolumn{2}{|l|}{ Lowest 70 percent } & 24.91 & 32.75 \\
\hline \multicolumn{2}{|l|}{ Lowest 80 percent } & 36.68 & 44.88 \\
\hline \multicolumn{2}{|l|}{ Lowest 90 percent } & 53.76 & 59.14 \\
\hline \multirow[t]{2}{*}{ All Farms } & & 100.00 & 100.00 \\
\hline & \multicolumn{3}{|c|}{ Land Concentration Ratios } \\
\hline (1) & Farm Area Basis & 0.62 & 0.54 \\
\hline (2) & Cultivated Area Basis & 0.58 & 0.47 \\
\hline (3) & Cropland Basis & 0.53 & 0.42 \\
\hline
\end{tabular}

Source: Calculated on the basis of the information in [52, p. 64 and 62, p. 1].

Note: The data on operational holdings in the two censuses may not be strictly comparable. It should, however, be noted that the calculated land concentration ratios reported in this paper are not widely different from those calculated by Khan [37, p.85] on the basis of ownership records.

land share of the largest 10 percent of the farms fell from 46.24 percent in 1960 to 40.86 percent in 1972 . Similarly, while the land share of the smallest 20 percent of the farms was 1.44 percent and 3.02 percent in 1960 and 1972 respectively, the corresponding figures for the largest 20 percent were 63.32 percent and 55.12 percent. In general, the small farms seem to have gained in land shares between 1960 and 1972 at the expense of the large ones. It may be interesting to note that the bottom 50 percent of the farms witnessed a 7 percent increase in land share between 1960 and 1972 with a corresponding decline in the land share of the top 50 percent. The exact magnitude and trend of land distribution follow from land concentration ratios, which fell significantly over the period under consideration. For example, while land concentration ratios based on farm area declined from 0.62 to 0.54 between 1960 and 1972 , this decline was from 0.58 to 0.47 and from 0.54 to 0.42 respectively if the bases of calculation were cultivated area and cropland area. These figures exhibit a 13-21 percent decline in land concentration over the 12-year period.

While the distribution of land appears to have improved, it may be argued that a number of factors, including land reforms, operation of inheritance laws, large farmers' attempt to increase their operational size in response to Green Revolution and consolidation of land holdings, may have contributed to this improvement. In so far as land reforms and inheritance laws are likely to add to the number and area of small farms, they do not seem to be significant factors because the number and area of small farms between 1960 and 1972 actually fell substantially. Although the large farmers increased self-cultivated and rented-in land, their efforts to enlarge operational holdings were unsuccessful: The average size of large farmers' holding went down from 112.5 acres in 1960 to 100.0 acres in 1972. This could have been due to the fact that large farmers rented out more land than they rented in, thus enabling many a small and medium farmer to move up the farm-size ladder. That this might be the case is reflected by the rising numbers and area of the farm-size categories exceeding 7.5 acres. The same could happen if some of the small farmers moved out of agriculture to take up jobs elsewhere, renting out or selling off their land to the neighbouring small and medium farmers. The question of job opportunities will be taken up shortly. It is important to note here that some 14.7 million acres were affected by the land-consolidation programme between 1959-60 and 1971-72 [63, p.48]. One of the major consequences of this has been the increase in the average size of small farms from 4.14 acres in 1960 to 5.82 acres in 1972. In view of this evidence the generally-held opinion that Green Revolution enabled large farmers to increase their farm size at the expense of smaller ones cannot be sustained.

\section{Implications for Distribution of Rural Income}

The evidence presented so far shows that the narrowing of inter-farm income disparities with the progressive adoption of Green Revolution technologies over time is mainly attributable to the induced changes in productivity levels and a more egalitarian distribution of land holding. It should be instructive in this connection to study intertemporal trends in farm income distribution. Table 3 gives income variations for small and large farmers over time along with small farm incomes as a percentage of large farm incomes.

Although absolute income differences between the two groups widened, between 1965-66 and 1970-71, there has been considerable narrowing of the relative income disparity between the small and large farms. Thus, while the small farmer, in 1965-66, earned only 9.2 percent of the large farmer's income, his income as percentage of the large farmer's income rose to 15.8 in 1970-71. This is to say that Green Revolution has not led a worsening of the relative income position 
of the small farmers. Given the fact that much of the growth between 1965-66 and 1970-71 is attributable to greater dependence on Green Revolution technologies [13, pp.11-12], it is tempting to conclude that Green Revolution has been responsible for the progressive narrowing of relative income differences between small and large farmers.

Table 3

Net Average Farm Incomes (in Current Prices) of Small and Large Farmers, 1965-66 to 1970-71

\begin{tabular}{cccc}
\hline \multirow{2}{*}{ Years } & \multicolumn{2}{c}{ Net Average Income in Rupees } & \multirow{2}{c}{$\begin{array}{c}\text { Col. (2) as Per- } \\
\text { cent of Col. (3) }\end{array}$} \\
\cline { 2 - 3 } & Small Farmers & Large Farmers & \\
\hline$(1)$ & $(2)$ & $(3)$ & $(4)$ \\
\hline $1965-66$ & 1288.4 & 14037.0 & 9.2 \\
$1966-67$ & 2037.2 & 18700.7 & 10.9 \\
$1967-68$ & 2435.7 & 16353.5 & 14.9 \\
$1968-69$ & 2367.2 & 17635.3 & 13.4 \\
$1969-70$ & 2838.0 & 24808.8 & 11.4 \\
$1970-71$ & 3290.7 & 20899.0 & 15.8 \\
\hline
\end{tabular}

Source: Calculations based on data in Table 2, [52, p.64 and 62, p.1]

\section{GROWTH OF INCOME OF THE RURAL LANDLESS AND LAND-OWNERS}

The inhabitants of rural areas residing outside the towns each having a population of 10 thousand or more, consists of the rural landless and land-owners. The rural landless are composed of tenants and landless agricultural and non-agricultural workers. In line with this occupational classification, the objective in this section is to study the income changes, first of tenants relative to those of land-owners, and then of landless rural workers relative to those of agricultural workers.

\section{Incomes of Tenants and Land-Owners}

What has been happening to the incomes of tenants relative to those of the land-owning class can be seen in the light of the data from Farm Accounts and Family Budgets (FAFB) of cultivators in the Punjab. Table 4 gives net farm incomes of big land owners, peasant proprietors and tenant cultivators from 1965-66 to $1970-71$
Table 4

Net Average Farm Incomes by Tenurial Classes: $1965-66$ to $1970-71$

\begin{tabular}{cccc}
\hline \multirow{2}{*}{ Years } & \multicolumn{3}{c}{ Net Average Farm Income (in Rupees) } \\
\cline { 2 - 4 } & $\begin{array}{c}\text { Big Land } \\
\text { Owners }\end{array}$ & $\begin{array}{c}\text { Peasant } \\
\text { Proprietors }\end{array}$ & $\begin{array}{c}\text { Tenant } \\
\text { Cultivators }\end{array}$ \\
\hline $1965-66$ & 4458.8 & 2532.2 & 1208.2 \\
$1966-67$ & 7292.9 & 3656.7 & 2090.0 \\
$1967-68$ & 6913.0 & 3873.8 & 2486.8 \\
$1968-69$ & 6856.3 & 4065.3 & 2668.8 \\
$1969-70$ & 7727.7 & 4779.2 & 3188.8 \\
$1970-71$ & 8309.8 & 5127.0 & 2915.8 \\
\hline
\end{tabular}

Source: Calculated from $[75 ; 76 ; 77 ; 78$ and 79$]$.

It is clear that the average net income of a big land owner was Rs. 4459 in $1965-66$, but had risen to Rs. 8310 by $1970-71$. Similarly, the net income of a peasant proprietor increased from Rs. 2532 in 1965-66 to Rs. 5127 in 1970-71 The corresponding figures for the tenant cultivators were Rs. 1208 and Rs. 2916 In other words, over the period under consideration, the net income of a tenant cultivator showed a 150 percent increase in contrast to a doubling of the incomes of peasant proprietors and a less than 100 percent increase in big-land owner's income In terms of annual growth rates, the tenant's net income grew at 19.3 percent, that of peasant proprietors rose by 15.2 percent and that of big land-owners increased by 13.3 percent.

This relatively higher growth rate of the tenants' income, though not a decisive evidence of an absolute improvement in the real incomes of the rural poor, does show that like the other two tenurial classes, this class also did not experience any income decline during the period under consideration. This finding also contradicts the generally-held view that the introduction of tubewells and tractors necessarily leads to a sharp decline in the relative shares of the tenants in total agricultural output [5, p.337].

\section{Green Revolution and Rural Workers}

The present sub-section studies the effect of Green Revolution on rural employment and rural wages. 


\section{Trend of Rural Employment}

Labour force surveys by the Government of Pakistan are one of the major sources of information on level of employment, and on rural employment in Pakistan $[47 ; 48 ; 57 ; 58 ; 59 ; 60$ and 61$]$. These data show that employment in rural areas was about 98 percent of the total rural labour force. One of the reasons for the unusually high rates of rural employment may be the inclusion of under-employed individuals in employment estimates. Such estimates constitute some 11-21 percent or $4-8$ percent of the labour force respectively depending on whether the underemployed are defined as those working less than 35 hours per week or as those working less than 25 hours per week. There seems to be no consistent intertemporal trend in the rates of employment or underemployment [11, p.15]. One of the implications of the constancy of employment and underemployment over time is that the rate of growth of rural job opportunities has been as fast as the rate of growth of the rural labour force.

The growth of job opportunities in the crop-production sub-sector depends on intertemporal changes in cropland area and labour intensity. While the changes in cropland may be self-explanatory, the changes in labour intensity are a function of the changes in the cropping pattern and those in the physical input of labour per crop-acre of various crops. It is evident from the Appendix that cropland, labour input per acre and cropping pattern have tended to contribute positively to growth of job opportunities in the crop-production sub-sector in Pakistan. The data presented in Table 5 are designed to give a precise magnitude of the growth of job opportunities due to each of the above factors during various time periods.

Table 5

Annual Growth Rates of Job Opportunities in the Crop Production Sub-Sector for Various Periods*

\begin{tabular}{ccccc}
\hline \multirow{2}{*}{ Period } & \multicolumn{3}{c}{$\begin{array}{c}\text { Annual Growth Rates (Percent) due to } \\
\text { Increase in }\end{array}$} & $\begin{array}{c}\text { Total Annual } \\
\text { Growth Rate } \\
(2+3+4)\end{array}$ \\
\cline { 2 - 3 } & Cropland & Labour Input & $\begin{array}{c}\text { Cropping } \\
\text { Pattern }\end{array}$ & \\
\hline$(1)$ & $(2)$ & $(3)$ & $(4)$ & $(5)$ \\
\hline $1964-1968$ & 1.88 & 0.69 & 0.72 & 3.29 \\
$1968-1972$ & 0.77 & 0.73 & 0.20 & 1.70 \\
$1972-1976$ & 1.32 & 0.73 & 0.75 & 2.80 \\
$1964-1976$ & 1.32 & 0.72 & 0.56 & 2.60 \\
\hline
\end{tabular}

Source: Calculated from data in the Appendix. Table.
It is clear that job opportunities in the crop-production sector have expanded considerably over the period under consideration. It may be noted that the increase in job opportunities amounted to a maximum of 3.29 percent during the period from $1962-63 / 1965-66$ to $1966-67 / 1969-70$ and to a minimum of 1.70 percent during the following four years. The growth rate for the entire period was 2.60 percent per year. (This compares with the growth rate of $2.29-2.83$ percent given in an independent study [13, p.105] for the period from 1967-68 to 1975-76). Among the three factors, the increase in cropland made the maximum contribution to the growth of jobs. The contribution of physical labour input as well as of cropping pattern, although less pronounced than that of cropland, can by no means be regarded as insignificant. In fact these two factors, both individually and jointly, have been responsible for a sizeable proportion of the growth rate of job opportunities in the crop-production sector throughout the period under consideration.

To appraise the employment situation in the crop production sector, it is necessary to compare the growth rates of job opportunities with the growth rates of agricultural labour force. This, unfortunately, is difficult to accomplish for lack of consistent time-series data, especially for the most relevant period, the late Sixties. For example, the agricultural labour force grew by 1.88 percent per annum between 1951 and $1961[16$, p.308], but the growth rate of labour force was more than 3.6 percent per annum for the intercensal period 1961-72 [1, p.124]. The latter growth rate seems to be unbelievably high and has been regarded by most of the experienced demographers to be the result of distortions of data in the 1961 and 1972 population censuses. Thus the use of census data, without appropriate adjustment [38, p.182] for distortions, may not be safe. Although the United Nation's estimates of agricultural labour force [89, p.67] may be questionable, the reported data may be relatively distortion-free because these estimates are nothing but the data supplied by the government itself adjusted for any distortions and unobservable abnormalities. Reliance on the U.N. estimates yields a growth rate of 1.66 percent per year for the agricultural labour force between 1965 and 1977. A growth rate of 1.66 percent per annum from the mid-Sixties to 1977 compared to that of 1.88 percent for the Fifties should make sense in view of the expansion of the non-agricultural rural sector associated with the steep rise in agricultural output, rapid growth of jobs in the urban formal (large- and small-scale industries) and informal sectors [13, pp.109-114], and the accelerating international migration of Pakistani labour. According to a survey conducted at the PIDE [18, Part I] there were an estimated 1.8 million Pakistani workers working abroad by January 1979.

Due mainly to a faster increase in job opportunities than in labour force, employment situation in the crop-production sector consistently improved during the Sixties and the Seventies. Since the crop-production sector is one of the major sources of rural employment, a considerable tightening of the rural labour market should be expected. In fact, it was reported in 1974 [24, p.58] that most of the 
cultivators experienced difficulties in hiring enough labour for various operations. The situation in recent years, as may be perceived by visits to rural areas, seems to have worsened. ${ }^{3}$

Contrary to the widely-held opinion, the improvement of employment in the crop-production sector was mainly induced by Green Revolution as it increased multiple-cropping $[10$, p. $33 ; 29$, p.54 and 41 , pp.74-75], augmented farm productivities [41, pp.87-91 and 19, p.18], shifted the cropping pattern in favour of more valuable labour-intensive cash crops [41, pp.74-75], added directly, except in the case of tractors, to labour input per acre [10, p.103 and 32, p.76], and created new jobs both within and outside agriculture [13, pp.109-114]. Given this background, it may be interesting to study the individual effects of different Green Revolution technologies on employment in Pakistan in the light of available evidence.

Bose and Clark conjectured that labour requirements on tractorized farms may be half of those on traditional farms [9, p.289]. However, this conjecture is unrealistic as Bose and Clark (i) did not take into account the fact that tractors in Pakistan are restricted to operations, like preparatory tillage, [31, p.386 and 90, p.89] where labour displacement could not have exceeded 5-10 percent; (ii) ignored the rise in employment induced by the increase in cropping and land use intensities due to tractors $[11$, p. 44]; and (iii) gave no consideration to substitution of family and casual labour for permanentlyhire labour. Probing somewhat more deeply and accounting for the inherent biases of the above study, Ahmad [3, p.30] has shown that tractors are unlikely to result in a reduction of permanent labour use, except that a third of the permanentlyhired labour may be replaced by a third of family labour. In addition, the casual labour requirement is increased by 5-35 percent (with an average of 20 percent) in major areas of Pakistan. Similar conclusions follow from Naseem's work. His data show that selective mechanization, by removing tillingpower constraint, is likely to lead to greater employment in agriculture [44, p.230].

While the employment effects of tractorization remain disputable, the increased labour demand induced by Green Revolution flowed from higher tubewell installations, greater fertilizer use and the introduction of HYVs. Labour requirements for harvesting, weeding and care of HYVs are estimated according to a U.S.AID study by Gill $[19$, p.9], to have increased by $20-40$ percent in Pakistan. Rochin [81, p.284] indicates a 50-percent increase in labour input following the introduction of Mexican Wheat in Pakistan. The same varieties in the Indian Punjab led to a two-fold to five-fold increase in labour input compared to local wheat [87, p.291]. In the case of Pakistan, labour input on tubewell farms was estimated to be 57 percent higher than on non-tubewell farms [32,p.76].

${ }^{3}$ In my conversations with of ficials of agricultural department, I was given the impression that most cultivators in the Punjab face severe shortages of manual labour, especially during the peak-demand seasons.
The above discussion, however, is concerned only with the direct employment effect of Green Revolution, ignoring its indirect effects. For example, Green Revolution has been associated with the rapid development of tubewell-related small-scale industry, repair-shop business for tubewells and tractors, electric transmission lines, distribution centres for fertilizer and diesel oil, and transportation service. More significantly, the Green Revolution technologies have strengthened forward and backward linkages between farm and non-farm sectors. When farm incomes rise, as under Green Revolution, the demand for key industrial goods begins to rise. The consequent expansion of the industrial sector not only provides more jobs but also increases the demand for agricultural produce.

Although the indirect employment effect of Green Revolution technologies may not be quantifiable, two instances of their significance may be cited. First, tubewell-manufacturing industry provided $7000-8000$ jobs in only five industrial towns of Pakistan [14, p.267]. Since, however, the development of tubewell industry has been widespread, this may be an under-estimate. In fact, another study, [31, p.387] reported that farmequipment manufacturers provided about 106,000 jobs in Pakistan at the end of the Sixties. Indeed, it stands to reason that the indirect employment effect of Green Revolution technology may have exceeded its direct effect $[88, p .106]$.

Thus, although the numbers of small farmers, tenants and permanent agricultural workers had declined between 1960 and 1972, the decline could not be attributed to deficiency in demand for labour under Green Revolution. Instead, it seems to be the result of shifts from permanent hired labour to greater use of casual and family labour and the movement of a number of tenants and small farmers from agriculture to non-agricultural jobs. The evidence is overwhelming that Green Revolution has been responsible for creating more jobs and for tightening the rural market. This, in turn, has had important implications for rural wage rates.

\section{Trend of Rural Wages}

The greater demand for labour generated by Green Revolution must have exercised an upward pull on the average rural wage rate. The data presented in Table 6 substantiate this expectation.

An upward trend in rural wages between 1951-52 and 1974-75 is clearly noticeable. A rural worker received Rs. 1.75 for a day's labour in 1951-52 in contrast to Rs. 4.68 in 1974-75. Although the wage rates have been rising consistently ove time, it is interesting to note that the rate of increase of rural wages was markedly higher during the late Sixties and early Seventies than during the Fifties and early Sixties. The reason for this acceleration seems to be the drying up of surplus-labour pool in the rural areas because of Green Revolution. 
Table 6

Daily Wages of Rural Workers for Various Years Constant Prices of 1959-60

\begin{tabular}{ccc}
\hline Year & $\begin{array}{c}\text { Real Wage Rate } \\
\text { (Rs. per day) }\end{array}$ & $\begin{array}{c}\text { Annual Growth Rate for } \\
\text { the Period Since the } \\
\text { last-mentioned Year }\end{array}$ \\
\hline $1951-52$ & 1.75 & - \\
$1959-60$ & 2.02 & 1.81 \\
$1964-65$ & 2.34 & 2.99 \\
$1969-70$ & 3.44 & 8.01 \\
$1974-75$ & 4.68 & 6.35 \\
\hline
\end{tabular}

Source: $[13$, pp. 119 and 136]

\section{Distributional Changes}

The investigation of the trend of income distribution between the rural landless and land-owners can begin with an analysis of the wage share. The wage share is defined as the proportion of national income accruing to wage earners. For the purpose of this study, the changes in wage share are the sum total of the rate of change of employment and that of wage rates relative to changes in agricultural out put $[13$, p.124]. The income share of the rural landless witnessed considerable improvement with the passage of time, especially after the onset of Green Revolution. For example, the wage increases of the late Sixties and early Seventies alone were in excess of growth rates of value added by agriculture in these periods. Adding up the growth rates of rural employment would substantially increase the share of the rural landless in total agricultural income.

\section{REGIONAL INCOME DIFFERENTIALS}

The case of growing regional disparities in the existing literature is based on the differential impact of Green Revolution on the incomes of irrigated and unirrigated areas on the one hand and various provinces of Pakistan on the other. It seems appropriate to study income disparities separately between irrigated and barani areas and among various provinces.

\section{Income Trend of Irrigated Versus Barani Areas}

Ideally one should compare incomes of two or more groups or regions for investigating changes in income distribution. This, however, seems to be impossible in the special case of barani and irrigated areas. This is because the ever-expanding irrigation facilities in Pakistan have tended to add to the size of the irrigated area at the expense of barani tracts (Appendix). It appears that the intertemporal comparisons of productivities of the two regions rather than those of incomes in this special case may be a more relevant measure of income distribution changes.

Table 7

Product per Acre Valued at 1959-60 Crop Prices for Barani and Irrigated Areas 1966-67 to $1974-75$

\begin{tabular}{cccc}
\hline \multirow{2}{*}{ Years } & \multicolumn{2}{c}{ Product per Acre in Rupees } & $\begin{array}{c}\text { Col. (2) as } \\
\text { Percent of } \\
\text { Col. (3) }\end{array}$ \\
\cline { 2 - 3 } Barani Areas & Irrigated Areas & $(3)$ & $(4)$ \\
\hline $1966-67$ & $(2)$ & 158.5 & 23.5 \\
$1967-68$ & 37.3 & 169.6 & 29.4 \\
$1969-70$ & 49.8 & 202.1 & 21.9 \\
$1970-71$ & 44.3 & 186.0 & 23.3 \\
$1971-72$ & 43.4 & 194.3 & 24.9 \\
$1972-73$ & 48.4 & 195.0 & 26.2 \\
$1973-74$ & 51.0 & 194.7 & 24.2 \\
$1974-75$ & 47.2 & 192.2 & 27.7 \\
\hline
\end{tabular}

Source: $[13$, p. 149].

Table 7 shows that productivity of the barani areas is considerably lower than that of the irrigated ones. This may not all be surprising in view of the dependence of crop production in the barani areas on natural precipitation. However, despite this limitation, the barani areas seem to have competed very well with irrigated areas in terms of their ability to secure productivity gains. As should be evident from Table 7 , average productivity in the barani areas went up at an annul compound growth rate of 4.6 percent in contrast to the productivity growth of 2.4 percent in the irrigated areas between 1966-67 and 1974-75. As a result, the productivity gap between the two types of areas narrowed considerably. The above table also shows that relative to 1966-67, the productivity gap between the two regions narrowed in most of the years under consideration. This fact can be interpreted as a sign of an improvement in income distribution between barani and irrigated areas.

While the higher productivity gains of the barani areas relative to irrigated ones may seem add in view of the significance of water in crop-production, three factors may explain this paradox. First, while water may be a limiting factor, the majority 
of the barani areas in Pakistan seem to be endowed with sufficient rain to allow successful cultivation of HYVs of wheat. For example, a study of 200 barani farms in Hazara district [81, p.276], with as much annual rainfall as in other unirrigated areas, shows that as in the irrigated areas, the introduction of HYVs doubled wheat yields. Secondly, mechanized cultivation with tractors could greatly increase the water conservation potential of the barani areas and add to crop-yields. It has been shown that a four-fold increase in barani wheat yields, in contrast to $10-20$ percent increase in the irrigated areas, could be brought about with proper mechanization of tillage operations [80]. Thirdly, dwarf wheat varieties require slow and gradual temperature changes from the month of March onward for successful maturity. The unirrigated mountainous regions seem to be better suited than the irrigated plains to the production of dwarf wheat varieties from this point of view.

\section{Inter-Provincial Income Differentials}

In the absence of data on gross provincial products, the problem of interprovincial income disparity in agriculture may be analysed on the basis of the trends of gross values of agricultural output at some base-year prices. For the purpose in hand, Table 8 presents gross value of agricultural commodities by provinces and plan periods, at 1959-60 Multan market prices along with their growth rates.

It is evident from Table 8 that the Punjab accounts for most of the agricultural output in Pakistan. By contrast, very little is produced in the province of Baluchistan. In spite of this, the Punjab has never been a leader in the growth of agricultural output. Instead, as the table shows, the provinces of Sind and Baluchistan seem to have consistently out-performed the Punjab during most of the plan-periods under consideration. Although the overall growth of agricultural output in the N.-W.F.P. has been slower than that in the Punjab, the annual growth rates of the N.-W.F.P. exceeded those of the Punjab in two of the four plan-periods under consideration.

Following the differential growth performance of various provinces, the production shares of Baluchistan and Sind have increased substantially at the expense of falling shares for the N.-W.F.P. and the Punjab with the passage of time. The data in Table 8 could be used to show that the respective production shares of the N.-W.F.P. and the Punjab went down from 10.7 percent to 9.0 percent and from 68.4 percent to 62.6 percent between $1959-60$ and 1979-80. While Baluchistan's share rose from 1.7 percent to 3.3 percent, the increase in the production share of Sind was from 19.2 percent to 25.1 percent between the corresponding periods. However, it may not be unjustified to make a claim about an improvement of income distribution among the four provinces on the basis of cumulative population and production shares. For although the cumulative production share for the poorest 20 percent of the population (Baluchistan and the N.-W.F.P. combined) remained constant, there was a definite improvement in the production share of the poorest 4 percent and that of the poorest 40 percent (total of Baluchistan, the N.-W.F.P. and Sind) of the population between 1959-60 and 1979-80.

Table 8

Provincial Gross Value * of Agricultural Commodities (at 1959-60 Prices) for Various Time Periods

\begin{tabular}{|c|c|c|c|c|c|}
\hline Years & $\begin{array}{l}\text { Baluchi- } \\
\text { stan }\end{array}$ & N.-W.F.P. & Sind & Punjab & Pakistan \\
\hline \multicolumn{6}{|c|}{ A. Gross Crop Value (Rs. Million) } \\
\hline $1959-60$ & 92 & 585 & 1051 & 3736 & 5464 \\
\hline $1964-65$ & 228 & 850 & 1524 & 4775 & 7377 \\
\hline $1969-70$ & 322 & 948 & 2172 & 6731 & 10173 \\
\hline $1974-75$ & 368 & 1137 & 2733 & 7513 & 11751 \\
\hline $1979-80$ & 473 & 1291 & 3575 & 8924 & 14263 \\
\hline \multicolumn{6}{|c|}{ B. Annual Growth Rates (percent) } \\
\hline $1959-60$ to $1964-65$ & 19.9 & 7.8 & 7.7 & 5.0 & 6.2 \\
\hline $1964-65$ to $1969-70$ & 7.2 & 2.2 & 7.3 & 7.1 & 6.6 \\
\hline $1969-70$ to $1974-75$ & 2.7 & 3.7 & 4.7 & 2.2 & 2.9 \\
\hline $1974-75$ to $1979-80$ & 5.2 & 2.6 & 5.5 & 3.5 & 4.0 \\
\hline
\end{tabular}

Source: Calculations based on production data in [64;65 and 67] and price information in [49 and 50$]$.

*Gross value is the sum total of output of various crops multiplied by their respective 1959-60 prices for Multan market. The reported years pertain to mid-year of the three-year averages, except 1979-80 which refers to single year because productions data for 1980-81 are not available.

\section{Trend of Regional Income Distribution}

It follows from the evidence presented above that there is very little empirical evidence to support the widelyheld view that Green Revolution widened income disparity among the various regions of Pakistan. Instead, the narrowing down of the productivity gap between irrigated and unirrigated areas and the rising production shares of the poorer provinces of Pakistan over time are an indication of the positive contribution made by Green Revolution to the progressive reduction of regional income inequality. 


\section{SIZE DISTRIBUTION OF RURAL INCOMES AND ITS TREND}

The previous three sections have dealt with rural income distribution, disaggregated by classes and regions. Independent empirical evidence in each of these sections shows that inter-class and inter-regional income distributions have consistently been improving with the expanding role of Green Revolution technologies. Since the trend of functional and regional distribution of income shapes the trend of size distribution of income, it could be used to assess the validity of our earlier conclusions on the changing pattern of the rural income distribution.

Although the size distribution of rural incomes has completely been ignored in the existing literature, it may be of interest to note that the findings of size distribution studies in Pakistan [35, pp.1-39 and 4, pp.432-50] lend support to our conclusions. It seems appropriate at this point to go into a detailed analysis of the magnitude and trend of size distribution of rural incomes. As is usual, the analysis of income distribution could be undertaken in terms of income shares of various percentiles of households and in terms of Gini concentration ratios.

\section{Income Shares of Rural Households}

A study of the trend of income distribution over time involves comparisons of income shares, of various household proportion at given point of time. Table 9 presents cumulative income shares for various percentiles of households.

It can be seen from Table 9 that the poorest 10 percent of the households in 1959 received 3.0 percent of the total income and 28.2 percent accrued to the richest 10 percent. In 1961, the share of the poorest 10 percent remained at 3.0 percent but that of the richest 10 percent fell to 27.4 percent. The poorest 10 percent accounted for 3.3 percent of the total income in 1963-64, which year showed a slight increase in the share of the richest 10 percent of the households. By 1966-67, the share of the lowest 10 percent rose to 4.0 percent and that of the top 10 percent declined to 25.9 percent. In $1968-69$, the lowest 10 percent continued to receive 4.0 percent of the total income, but there was a further decline in the share of the top 10 percent to 23.6 percent. The proportion of income accruing to the lowest 10 percent of the households fell to 3.8 percent in $1969-70$ with a more-than-corresponding increase in the income proportion of the richest 10 percent. While the share of the lowest 10 percent of the households remained at the 1969-70 level in 1970-71, the share of the top 10 percent fell further. The year 1971-72 witnessed a sharp improvement in the income share of the richest 10 percent and a slight fall in the income share of the lowest 10 percent of the rural households.

Comparisons of income shares between the lowest and the top households at the 20-percent and 40-percent levels reflect more or less the same picture as those at the 10-percent level. However, a more elaborate and interesting picture emerges from 
the comparison of income shares for the lower 50 percent of the house-holds as the relatively poorer group and the upper 50 percent as the relatively richer group. In 1959 , the lower half of the households in rural Pakistan accounted for only 25.8 percent of the total income. By 1970-71, as a result of consistent improvement, their share of total income peaked at 30.4 percent but fell to 29.5 percent in 1971-72. In contrast, 74.2 percent of the total income accrued to the richer half of the rura households in 1959. It had declined to 69.6 percent by $1970-71$ but then rose to 70.5 percent of the total income in 1971-72. It thus follows from the above that an increasing proportion of rural incomes has accrued to the poorer half and a decreasing proportion to the richer half of the rural households over time. This implies that there has been a considerable narrowing of the income differential between rural households from the early Sixties to the early Seventies.

\section{Income Concentration Ratios}

Income concentration ratios or Gini coefficients allow measurement of the precise degree of income inequality. Table 10 presents income concentration ratios for rural households and rural population separately.

Table 10

Rural Household and Per Capita Income Concentration Ratios for Various Years

\begin{tabular}{lcc}
\hline \multirow{2}{*}{ Years } & \multicolumn{2}{c}{ Income Concentration Ratio Based on } \\
\cline { 2 - 3 } & Household Income & Per Capita Income \\
\hline 1959 & 0.348 & 0.228 \\
1961 & 0.357 & 0.203 \\
$1963-64$ & 0.348 & 0.223 \\
$1966-67$ & 0.319 & 0.186 \\
$1968-69$ & 0.294 & 0.161 \\
$1969-70$ & 0.295 & 0.161 \\
$1970-71$ & 0.291 & 0.146 \\
$1971-72$ & 0.308 & 0.164 \\
\hline
\end{tabular}

Source: Calculations based on data in $[12 ; 46 ; 51 ; 53 ; 54 ; 55$ and 56$]$.

It can be observed from Table 10 that the income concentration ratios, whether based on household or on per capita incomes fell considerably between the early Sixties and the Seventies. The decline, however, has not been uniformly distributed over time. In 1959, 1961 and 1963-64, the income concentration ratios based on household income, in spite of some increase between 1959 and 1961, remained in the neighbourhood of 0.350. Between 1963-64 and 1968-69, some of the sharpest declines occurred in the income concentration ratios, which fell from their level of the early Sixties (0.350) to 0.319 in 1966-67 and to 0.294 in 1968-69. Relative to $1968-69$, the Gini coefficient rose in $1969-70$ and declined in 1970-71. The income concentration ratio rose significantly in 1971-72, to lie above the levels attained during 1968-69, 1969-70 and 1970-71. The income concentration ratios based on per capita incomes show more or less the same trend as those based on household incomes.

It follows from the discussion on income shares and income concentration ratios that rural income inequalities in the late Sixties and early Seventies were considerably lower than those of the pre-Green Revolution period of early to midSixties in Pakistan in spite of the somewhat deteriorating trend between 1970-71 and 1971-72. Although size distribution data for the years following 1971-72 are not yet available, improvement of size distribution of income beyond this period can be anticipated in the light of the improving income distribution among various classes and regions of Pakistan.

\section{CONCLUSIONS}

It has been alleged that Green Revolution has widened rural income inequalities in Pakistan. The purpose of this paper has been to investigate, using Pakistani data, the legitimacy of this claim. This study has shown that the use of fertilizers and HYVs is invariant with respect to size of farm. The same is true of tubewells and tractors, which are physically indivisible but their services are nearly divisible. And these services have been used by small farms to achieve the required degree of cultivation intensity. Input subsidies and support prices have been of enormous help to small farmers, considering their weak financial position. Higher labour input, more intensive land use, greater manurial application and lower managerial costs have enabled the small farms to enjoy higher productivity than large farms. Land distribution between 1960 and 1972 seems to have become less skewed in Pakistan and so has been the income distribution among farmers. Also, Green Revolution does not seem to have promoted tenant evictions. The falling number of tenants with a simultaneous increase in average farm size must be attributed to the fear of sweeping land reforms or to the growing shortages of tenants due to greater availability of alternative jobs. Although Green Revolution may have resulted in reduced tenant shares, it is unlikely that it caused a reduction in tenant incomes because tenant costs also fell. The empirical evidence in Pakistan seems to establish conclusively that net incomes of tenants have been increasing faster than those of land-owners. On the whole, Green Revolution appears to have been employment-creating. There has been no substitution of wheat for cotton and the induced changes in cropping pattern have tended to increase labour intensity in agriculture. Average wages in agriculture 
have increased at higher rates than agricultural output. Consequently, the share of wages in total output has risen substantially with the passage of time. There seems to be no case of widening regional disparities. Instead, the evidence is overwhelming that inter-regional income disparities have narrowed in the post-Green Revolution years. The size distribution of rural income is consistent with our conclusions of functional distribution and points to an improvement of rural income distribution between the early Sixties and the early Seventies. In short, Green Revolution in Pakistan seems to have been growth-inducing and employment-creating. It also reduced inequality between income classes and regions. Several studies in recent years could be cited in support of the conclusions of this study [2; 7; $8 ; 13 ; 17 ; 34$ and 40$]$. Based on such considerations, Green Revolution has been regarded for most countries to be the necessary precondition for achieving higher growth level [2, p.298] and greater rural employment, and for buying more welfare for the poor [40, p.23]. The pursuit of greater social equality [17] and a more egalitarian distribution of income has also been helped by Green Revolution [6, pp. 126-129]

While Green Revolution has been beneficial, its inherent potential is best realized when it gets support from government policies [40, p.23]. Depending on past experience and likely future developments in Pakistan's agriculture, five policy actions may be recommended. As has been argued in this paper, favourable terms of trade for agriculture in the form of liberal input subsidies and active price supports for major agricultural commodities were key factors in the promotion of the cause of Green Revolution during the Sixties. Such a beneficial policy is now being abandoned. For instance, subsidies on key agricultural inputs like chemical fertilizers, diesel oil, electricity, insecticides and tubewell equipment, are being withdrawn. A procurement-price policy offering prices for agricultural commodities that are much below the international market prices is replacing the price support policy of the Sixties. The present study suggests that, unless such policies are reversed, the impetus of the Green Revolution technologies is most likely to suffer a slow-down. This, in turn, will adversely affect the growth rates of investment, economic development and employment in agriculture.

However, a continuation of input subsidies may be undesirable for it involves mounting financial burdens for the government. Rapidly increasing fertilizer consumption and the consequent import needs are the principal causes of the rising subsidy bills. Since the cost of production of domestically-produced fertilizer is much below the international or domestic fertilizer prices at present, the government subsidy costs can be sharply curtailed or altogether eliminated if the dependence on import is reduced for attaining self-sufficiency in fertilizer production. In addition to a suitable price policy, a timely and satisfactory provision of agricultural inputs and services would be of immense importance for agricultural growth. The present system of controlled input supplies through registered dealers needs to be expanded and supplemented by free market sales in order to curb black marketing and to make the system more efficient in terms of easy access for the farming community.

Agricultural production, in the near future, is likely to be constrained by severe shortages of labour, especially at the peak-demand periods. As pointed out earlier, such shortages, perhaps, have already begun to appear in certain seasons and regions of Pakistan. It would, therefore, be appropriate to study the emerging situation in detail on an all-Pakistan basis now and to prepare plans to combat the severity of labour shortages in rural areas. In this regard, the importance of mechanization of certain agricultural operations should not be underestimated. Although mechanization is labour-displacing and may conflict with the objective of employmentpromotion in the agricultural sector, the effect of a gradual and partial mechanization on labour-displacement should not be too severe.

The development of the small-scale agriculture-related industry - manufacturing of electric motors, diesel engines, agricultural implements and tubewell equipment - has played a vital role in the success of Green Revolution and in employment - generation in rural and urban areas. It should be of immense social value if the government subsidized the creation and development of such agro-based industries. Among other things, such industries, by generating additional employment, may slow down, if not altogether stop, the process of rural-urban migration. 
Total Area of Crops, Cropping Pattern and Labour Input per Acre by Crops for Various Years

\begin{tabular}{|c|c|c|c|c|c|c|c|}
\hline & \multirow{2}{*}{$\begin{array}{l}\text { Irrigation Status } \\
\text { and Crops }\end{array}$} & \multicolumn{4}{|c|}{$\begin{array}{l}\text { Crop Shares (percent) } \\
\text { in Total Area }\end{array}$} & \multicolumn{2}{|c|}{$\begin{array}{l}\text { Labour Input (Man-days) } \\
\text { per acre }\end{array}$} \\
\hline & & $\begin{array}{l}1962-63 / \\
1965-66\end{array}$ & $\begin{array}{l}1966-67 / \\
1969-70\end{array}$ & $\begin{array}{r}1970-71 / \\
1973-74\end{array}$ & $\begin{array}{c}1974-75 / \\
1977-78\end{array}$ & $1969-70$ & $1975-76$ \\
\hline \multirow[t]{15}{*}{ A. } & Irrigated (Sub-total) & 74.5 & 77.0 & 78.7 & 79.5 & & \\
\hline & Wheat & 22.9 & 26.1 & 26.4 & 26.6 & 37.37 & 40.69 \\
\hline & Rice & 8.9 & 9.3 & 8.9 & 9.9 & 33.46 & 34.73 \\
\hline & Cotton \& other Fibers & 10.1 & 10.8 & 11.3 & 10.9 & 43.24 & 47.07 \\
\hline & Sugarcane & 3.6 & 3.6 & 3.5 & 4.2 & 162.70 & 169.50 \\
\hline & Maize & 2.2 & 2.6 & 2.7 & 2.5 & 45.67 & 45.30 \\
\hline & Bajra & 2.4 & 2.1 & 2.4 & 1.4 & 29.66 & 31.70 \\
\hline & Jowar & 2.0 & 1.1 & 1.9 & 1.5 & 29.47 & 29.93 \\
\hline & Barley & 0.5 & 0.5 & 0.7 & 0.5 & 9.50 & 9.50 \\
\hline & Gram & 3.3 & 2.8 & 1.8 & 1.6 & 40.97 & 32.31 \\
\hline & Tobacco & 0.3 & 0.4 & 0.3 & 0.3 & 89.68 & 87.22 \\
\hline & Oil-seeds & 3.3 & 2.9 & 3.1 & 2.6 & 29.76 & 30.75 \\
\hline & Fodder & 12.9 & 11.7 & 13.2 & 14.8 & 27.72 & 27.72 \\
\hline & Vegetable and Spices & 1.2 & 1.1 & 1.2 & 1.3 & 79.35 & 81.94 \\
\hline & Fruits & 0.9 & 1.0 & 1.3 & 1.4 & 67.23 & 67.23 \\
\hline
\end{tabular}

\begin{tabular}{lrrrrrr}
\hline B. Unirrigated (Sub-total) & 25.5 & 23.0 & 21.3 & 20.5 & - & - \\
Wheat & 10.9 & 10.2 & 9.1 & 8.4 & 11.00 & 11.00 \\
Maize & 1.1 & 1.1 & 1.1 & 1.0 & 16.00 & 16.00 \\
Bajra & 3.3 & 2.8 & 1.9 & 2.3 & 11.75 & 11.75 \\
Jowar & 1.2 & 1.0 & 1.2 & 1.1 & 7.75 & 7.75 \\
Barley & 0.6 & 0.6 & 0.6 & 0.5 & 11.75 & 11.75 \\
Gram & 4.8 & 3.8 & 4.1 & 4.2 & 0.75 & 13.00 \\
Oil-seeds & 0.4 & 0.6 & 0.6 & 2.4 & 10.25 & 10.25 \\
Pulses & 3.2 & 2.9 & 2.7 & & - \\
C. & & & & & - \\
\hline
\end{tabular}

Total Cropped Area (Million Acres)
38.0
41.0
42.3
44.5

Source: For cropping pattern calculations were based on the data given in $[34 ; 63 ; 64 ; 65 ; 66 ; 67 ; 68 ; 83 ; 84 ; 85$ and 86$]$. 


\section{REFERENCES}

1. Afzal, Muhammad. "1972 Census: Population - Expected and Actual" Pakistan Development Review. Vol. XII, No. 2. Summer 1973.

2. Ahluwalia, Montek S. "Rural Poverty and Agricultural Performance in India" Journal of Development Studies. Vol. 14, No. 3. April 1978.

3. Ahmad, Bashir. "Field Survey of Large Farmers in the Pakistan Punjab" Cambridge, Mass. (USA): Harvard University. 1972. Working Paper No. 7 Project on Rural Development in Pakistan. (Mimeographed)

4. Alauddin, Talat. "Mass Poverty in Pakistan : A Further Study". Pakistan Development Review. Vol. XIV No. 4. Winter 1975.

5. Alavi, Hamza. "The Rural Elite and Rural Development in Pakistan". In Robert D. Stevens et al. (eds.), Rural Development in Bangladesh and Pakistan. Honolulu: The University Press of Hawaii 1976.

6. Azam, A. K. "The Future of the Green Revolution in West Pakistan: A Choice of Strategy". International Journal of Agrarian Affairs. Vol. 5, No. 6. March 1973.

7. Baqai, Moinuddin. "Growth Strategies and Policies: Pakistan Experience". In Saeed Ahmad Qureshi and Muhammad Arif (eds.), Strategies of Planning and Development. Lahore: Planning and Development Board. 1978.

8. Bhattacharjee, J. P. "On Balance". In Thomas T. Poleman and Donald K. Freebairn (eds.), Food, Population and Employment: The Impact of Green Revolution. New York: Praeger Publishers. 1973.

9. Bose, S. R., and E.H. Clark. "Some Basic Considerations on the Agricultural Mechanization in West Pakistan". Pakistan Development Review. Vol. IX, No. 3. Autumn 1969.

10. Brown, Lester R. Seeds of Change:The Green Revolution and Development in the 1970s. New York, Washington and London: Praeger Publishers. 1970.

11. Chaudhry, M. Ghaffar. "Rural Employment in Pakistan: Magnitude and some Relevant Strategies". Research Report Series No. 131. Islamabad: Pakistan Institute of Development Economics. October 1981

12. Chaudhry, M. Ghaffar. "Rural Income Distribution in Pakistan in the Green Revolution Perspective". Pakistan Development Review. Vol. XII, No. 3. Autumn 1973.

13. Chaudhry, M. Ghaffar. "The Green Revolution and Income Inequality: Some Empirical Evidence from Rural Pakistan 1960-1975”. Ph.D Dissertation, University of Wisconsin, Madison, Wis. (USA). 1980. (Unpublished)

14. Child, Frank C., and Hiromitsu Kaneda. "Links to the Green Revolution: A Study of Small-Scale Agricultural - Related Industry in the Pakistan Punjab". Economic Development and Cultural Change. Vol. 23. January 1975.
15. Falcon, W. P. "The Green Revolution: Second General Problems". American Journal of Agricultural Economics. Vol. 52. December 1970.

16. Farooq, Ghazi M. "Economic Growth and Changes in the Industrial Structure of Income and Labour Force in Pakistan". Economic Development and Cultural Change. Vol. 21. January 1973.

17. Franke, Francine R. "The Politics of Green Revolution: Shifting Patterns of Peasant Participation in India and Pakistan". In Thomas T. Poleman and Donald K. Freebairn (eds.), Food, Population and Employment: The Impact of the Green Revolution. New York: Praeger Publishers. 1973.

18. Gilani, Ijaz, M. Fahim Khan and Munawar Iqbal. "Labour Migration from Pakistan to the Middle East and its Impacts on the Domestic Economy". 3 Parts. Islamabad: Pakistan Institute of Development Economics. JuneJuly 1981. Research Report Nos. 126, 127 and 128. (Mimeographed)

19. Gill, Amjad A: Pakistan Agricultural Development and Trade. Washington, D.C. : U. S. D. A., Economic Research Service. February 1973.

20. Gotsch, Carl H. "Relationship Between Technology, Prices and Income Distribution in Pakistan's Agriculture: Some Observations on the Green Revolution". In Robert D. Stevens et al. (eds.), Rural Development in Bangladesh and Pakistan. Honolulu: The University Press of Hawaii. 1976.

21. Gotsch, Carl H. "The Green Revolution and Future Developments of Pakistan's Agriculture". In Robert D. Stevens et al. (eds.), Rural Development in Bangladesh and Pakistan. Honolulu: The University Press of Hawaii. 1976

22. Gotsch, Carl H. "Tractor Mechanization and Rural Development in Pakistan". International Labour Review. Vol. 107. February 1973.

23. Graffin, Keith. The Political Economy of Agrarian Change. Cambridge, Mass. (USA): Harvard University Press. 1974

24. Haider, Agha Sajjad, and P. Kuhnen. "Land Tenure and Rural Development in Pakistan". Land Reform, Land Settlement and Cooperatives. No. 1/2. 1974

25. Hamid, Naved, and Akmal Hussain. "Regional Inequalities and Capitalist Development". Pakistan Economic and Social Review. Vol. 12, No. 4. Autumn 1974.

26. Hasan, Pervez. "Agricultural Growth and Planning in the 1960s: An Introduction". In Robert D. Stevens et al. (eds.), Rural Development in Bangladesh and Pakistan. Honolulu: The University Press of Hawaii. 1976.

27. Herring, R., and M. Ghaffar Chaudhry. "The 1972 Land Reforms in Pakistan and Their Implication: A Preliminary Analysis". Pakistan Development Review. Vol. XIII, No. 3. Autumn 1974.

28. Hinjra, Ahmad Hassan, and M. Ibrahim Azad. "Gobar Khad Ki Ahmyat Aur Istimaal" (in Urdu). Zaraat Namah. December 1978. 
29. International Labour Organization: Employment Strategy - Pakistan 75/ Project: Findings and Recommendations. Geneva. 1977.

30. Johnston, B.F., and John Cownie. "The Seed-Fertilizer Revolution and Labour Force Absorption". American Economic Review. Vol. 59. September 1969.

31. Johnston, B. F., and Peter Kilby. Agriculture and Structural Transformation: Economic Strategies in Late-Developing Countries. New York: Oxford University Press. 1975.

32. Kaneda, H., and M. Ghaffar. "Output Effects of Tubewells on the Agriculture of Punjab”. Pakistan Development Review. Vol. X, No. 1. Spring 1970.

33. Khan, Dilawar Ali, and H. A. Chaudhari. "Income Impact of the Revolution". Pakistan Economic and Social Review. Vol. XI, No. 1. Spring 1973.

34. Khan, Dilawar Ali. "Employment and Occupational Change in the Rural Punjab: Consequences of Green Revolution". Employment Planning and Basic Needs in Pakistan: Report of a National Conference Held at Islamabad, May 15-18, 1978. Islamabad: Pakistan Manpower Institute (Islamabad) and Asian Regional Team for Employment Promotion (Bangkok) May 1978.

35. Khandkar, R. H. "Distribution of Income and Wealth in Pakistan". Pakistan Economic and Social Review. Vol. 14, Special Issue. 1976.

36. Khan, M. H. The Economics of Green Revolution in Pakistan. New York, Washington and London: Praeger Publishers. 1975.

37. Khan, M. H. Underdevelopment and Agrarian Structure in Pakistan. Boulder, Colorado: Westview Press. 1981.

38. Krotki, Karol J. "Pakistan's Population Size and Growth in the Light of the 1972 Census Evaluation Survey". Pakistan Development Review. Vol. XV, No. 2. Summer 1976

39. Lowdermilk, M. K. "Preliminary Report of the Diffusion and Adoption of Dwarf Wheat Varieties in Khanewal Tehsil, West Pakistan". Ithaca: Cornell University. 1971. (Mimeographed)

40. Mellor, John W. The Impact of New Technology on Rural Employment and Income Distribution: Final Research Report. Ithaca, N.Y.: Cornell University. June 1974.

41. Muhammad, Ghulam. "Private Tubewell Development and Cropping Patterns in West Pakistan". Readings in Development Economics. Karachi: Pakistan Institute of Development Economics. February 1970. (Reading No. 3)

42. Myint, Hla. "Green Revolution in Southeast Area". In Gerald M. Meier (ed.) Leading Issues in Economic Development. New York: Oxford University Press. 1976.

43. Naqvi, Syed Nawab Haider, et al. The PIDE Econometric Model of Pakistan's Economy: (1959-60 to 1978-79). Islamabad: Pakistan Institute of Development Economics. 1982.
44. Naseem, Muhammad. "A Note on the Choice of Technology in Agriculture". Employment Planning and Basic Needs in Pakistan: Report of a National Conference Held at Islamabad, May 15-18, 1978. Islamabad: Pakistan Manpower Institute (Islamabad) and Asian Regional Team for Employment Promotion (Bangkok). May 1978.

45. Nulty, Leslie. The Green Revolution in West Pakistan: Implications of Technical Change. New York, Washington and London: Praeger Publishers. 1972.

46. Pakistan. Central Statistical Office. Household Income and Expenditure, 1963-64: Report on the Quarterly Survey of Current Economic Conditions in Pakistan. Karachi. 1964.

47. Pakistan. Central Statistical Office. Population and Labour Force in Pakistan, 1966-67. Karachi. 1970.

48. Pakistan. Central Statistical Office. Population and Labour Force in Pakistan (July 1967 - June 1968). Karachi. 1971.

49. Pakistan. Cooperation and Marketing Adviser. Markets and Prices. Vol. 11, No. 12. Karachi. (December 1959)

50. Pakistan. Cooperation and Marketing Adviser. Markets and Prices. Vol. 12, No. 12. Karachi. (December 1960).

51. Pakistan. Economic Affairs Division. Central Statistical Office. Household Income and Expenditure 1966-67: Report on the Quarterly Survey of Current Economic Conditions in Pakistan. Karachi. 1973.

52. Pakistan. Ministry of Agriculture and Works. Agricultural Census Organization. Pakistan Census of Agriculture 1960 All Pakistan Report 1: Data by Detailed Size Classification. Karachi. March 1964.

53. Pakistan. Ministry of Finance. Planning and Development. Statistical Division. Household Income and Expenditure Survey 1968-69. Karachi. 1973.

54. Pakistan. Ministry of Finance. Planning and Development. Statistical Division. Household Income and Expenditure Survey 1969-70. Karachi. 1973.

55. Pakistan. Ministry of Finance. Planning and Development. Statistical Division. Household Income and Expenditure Survey 1970-71. Karachi. 1973.

56. Pakistan. Ministry of Finance. Planning and Development. Statistical Division. Household Income and Expenditure Survey 1971-72. Karachi. 1973.

57. Pakistan. Ministry of Finance. Planning and Development. Statistical Division. Labour Force Survey 1968-69. Karachi. 1973.

58. Pakistan. Ministry of Finance. Planning and Development. Statistical Division. Labour Force Survey 1969-70. Karachi. 1973.

59. Pakistan. Ministry of Finance. Planning and Development. Statistical Division. Labour Force Survey 1970-71. Karachi. 1973.

60. Pakistan. Ministry of Finance. Planning and Development. Statistical Division. Labour Force Survey 1971-72. Karachi. 1973. 
61. Pakistan. Ministry of Finance. Planning and Development. Statistical Division Labour Force Survey 1974-75. Karachi. 1978.

62. Pakistan. Ministry of Food and Agriculture. Agricultural Census Organization. Pakistan Census of Agriculture 1972: All Pakistan Report, Data by Provinces (excluding Mala Kand Division and the Tribal Area). Lahore. 1975.

63. Pakistan. Ministry of Food, Agriculture and Cooperatives. Food and Agriculture Division. Planning Unit. Agricultural Statistics of Pakistan 1977. Islamabad. 1978.

64. Pakistan. Ministry of Food, Agriculture and Cooperatives. Food and Agriculture Division. Planning Unit. Agricultural Statistics of Pakistan 1979. Islamabad. 1980.

65. Pakistan. Ministry of Food, Agriculture and Cooperatives. Food and Agriculture Division. Planning Unit. Agricultural Statistics of Pakistan 1980. Islamabad.1981.

66. Pakistan. Ministry of Food, Agriculture, Cooperatives and Land Reforms. Food and Agriculture Division. Planning Unit. Survey Report on Cost of Production of Important Crops in Pakistan. Islamabad. 1977.

67. Pakistan. Ministry of Food, Agriculture, Cooperatives, Under Developed Areas and Land Reforms. Agriculture Wing. Planning Unit. Agricultural Statistics of Pakistan 1975. Vol. I. Islamabad. 1976.

68. Pakistan. Ministry of Food, Agriculture, Cooperatives, Under Developed Areas and Land Reforms. Agriculture Wing. Planning Unit. Agricultural Statistics of Pakistan 1975. Vol. II. Distict-wise Area and Production of Important Crops. Islamabad. 1977.

69. Pakistan. Ministry of Food, Agriculture and Under Developed Areas. Agriculture Wing. Year Book of Agricultural Statistics 1971-72. Islamabad. 1972.

70. Pakistan. National Fertilizer Corporation of Pakistan Ltd. A Study on Differential Impact of Fertilizer Price Increase on Its Use in Pakistan Kharif 1980. Lahore. (NFC-UFDC-World Bank Market Research Project). 1981.

71. Pakistan. National Fertilizer Corporation of Pakistan Ltd. A Study on Differential Impact of Fertilizer Price Increase on Its Use in Pakistan: Fertilizer Use Pattern in Pakistan Rabi 1980-81. Islamabad. (NFC-NFDC-World Bank Market Research Project). 1981.

72. Pakistan. National Fertilizer Corporation of Pakistan Ltd. Distribution and Use of Fertilizer in Pakistan: A Preliminary Report on General Farmer's Investigation Survey. Part 1 (NFC-USAID Market Research Project). Lahore. August 1976.

73. Pearse, Andrew. "Technology and Peasant Production: Reflections on Global Study". In Howard Newby (ed.) International Perspective in Rural Sociology. Chichester, New York, Brisbane and Toronto: John Wiley and Sons. 1976.
74. Punjab. Planning and Development. Statistical Survey Unit. Fertilizer and Mexican Wheat Survey Report. Lahore. 1973.

75. Punjab. Board of Economic Enquiry. Farm Accounts and Family Budgets of Cultivators in the Punjab 1965-66. Lahore. 1968.

76. Punjab. Board of Economic Enquiry. Farm Accounts and Family Budgets of Cultivators in the Punjab 1966-67 and 1967-68. Lahore. 1971.

77. Punjab. Board of Economic Enquiry. Farm Accounts and Family Budgets of Cultivators in the Punjab 1969-70. Lahore. 1972.

78. Punjab. Board of Economic Enquiry. Farm Accounts and Family Budgets of Cultivators in the Punjab 1968-69. Lahore. 1972.

79. Punjab. Board of Economic Enquiry. Farm Accounts and Family Budgets of Cultivators in the Punjab 1970-71. Lahore. 1973.

80. Rana Tractors and Equipment Ltd. "Dry Land Farming Project in Pakistan" Islamabad. 1974. (Mimeographed)

81. Rochin, Refugio I. "The Adoption and Effects of high Yielding Wheats on Unirrigated Subsistance Holdings in Pakistan". In Robert D. Stevens et al. (eds.), Rural Development in Bangladesh and Pakistan. Honolulu: The University Press of Hawaii. 1976.

82. Salam, Abdul. "Factor Inputs Use and Farm Productivity on Different Farm Categories in the Punjab". Pakistan Development Review. Vol. XVII, No. 3. Autumn 1978.

83. Sind. Planning and Development Department. Bureau of Statistics. Crop Acreage Statistics of Sind: Kharif 1977. Karachi. October 1978.

84. Sind. Planning and Development Department. Bureau of Statistics. Crop Acreage Statistics of Sind: Rabi 1977-78. Karachi. January 1979.

85. Sind. Planning and Development Department. Bureau of Statistics. Development Statistics of Sind. Karachi. December 1974.

86. Sind. Planning and Development Department. Bureau of Statistics. Develop ment Statistics of Sind. Karachi. December 1978.

87. Staub, William J. and Melvin G. Blose. "Induced Technological Change in Developing Agricultures: Implications for Income Distribution and Agricultural Development". The Journal of Development Areas. Vol. 8. July, 1974.

88. Turnham, David. The Employment Problem in Less Developed Countries: $A$ Review of Evidence. Paris: OECD. 1971.

89. United Nations. Food and Agriculture Organization. FAO Production Year Book. Rome. 1978.

90. Yudelman, Montague, et al. Technological Change in Agriculture and Employ ment in Developing Countries. Paris: OECD. 1971. (Development Centre Studies, Employment Series No. 4) 